\title{
Knowledge of School Health Programme among Public Primary School Teachers in Sokoto Metropolis, Northwestern Nigeria
}

Abubakar AU1,3, Oche OM²,3, Awosan KJ ${ }^{2,3}$, Raji $I A{ }^{1,3}$, Abdullahi AM1, Kaoje $A U^{2,3}$

1Nigerian Field Epidemiology and Laboratory Training Program.

2Department of Community Health, Usmanu Danfodiyo University, Sokoto.

${ }^{3}$ Department of Community Medicine, Usmanu Danfodiyo University Teaching Hospital, Sokoto.

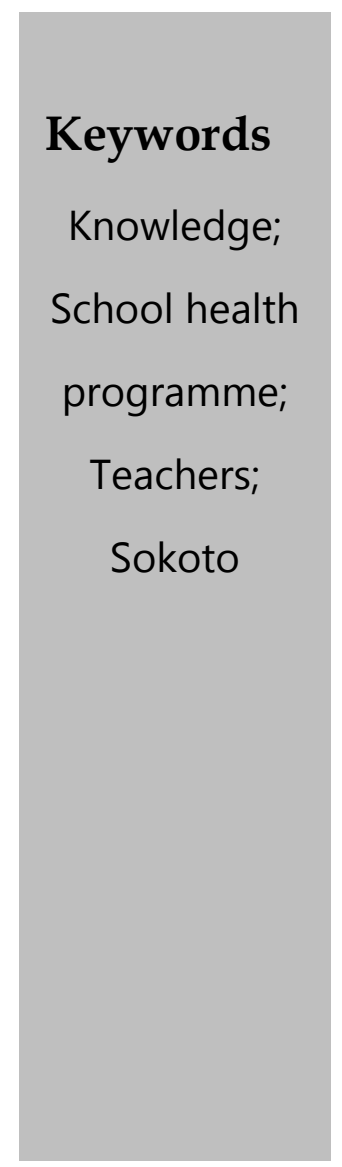

\section{ABSTRACT}

Background: School health program takes care of the health needs of a significant proportion of the population, especially in the third world countries, by ensuring that children of school age remain healthy and benefit maximally from their education. This study aimed to assess the knowledge of School Health Programme (SHP) among primary school teachers in Sokoto metropolis, northwestern, Nigeria.

Methods: A cross-sectional study was conducted among 382 public primary school teachers that were selected by multistage sampling technique. Data was collected using a structured, self-administered questionnaire. Proportions and adjusted odds ratios (OR) were calculated with $95 \%$ confidence intervals (CI) in a binary logistic regression model. All levels of significance were set at $\mathrm{p}<0.05$

Results: The mean age of the respondents was $34.8 \pm 8.6$ years. More than half of the respondents were Nigerian Certificate in Education (NCE) holders 245 (64.1\%). Knowledge of SHP was good in $198(51.8 \%)$ of the respondents. The predictors of good knowledge were belonging to other ethnicity (aOR: 3.70; 95\% CI=1.11-12.50, $\mathrm{p}=0.034$ ), having degree or postgraduate qualification in education (aOR: 4.55; 95\% CI=2.63-7.69, $\mathrm{p}<0.001$ ) and having worked for two or more decades (aOR: 4.15; 95\% CI=1.34-12.78, $\mathrm{p}=0.011)$

Conclusion: Nearly half of the respondents had poor knowledge of SHP and this is likely to deny a large number of school children of being healthy and benefitting from th eir education. Awareness campaigns and trainings on SHP to fill in the knowledge gap is highly recommended.

\section{INTRODUCTION}

School health programme (SHP) is an important element of an effective health care delivery system of any country. It takes care of the health needs of a significant proportion of the population, especially in the third world countries by ensuring that

\begin{abstract}
Correspondence to: Auwal Usman Abubakar Department of Community Medicine, Usmanu Danfodiyo University Teaching Hospital, Sokoto E-mail: auabubakar17@gmail.com
\end{abstract}

children of school age remain healthy and benefit maximally from their education. It is a group of coordinated activities which contributes to the understanding, maintenance and improvement of the health of the school population. ${ }^{1}$ In concept and practice, it is multidisciplinary and involves 
inter-sectoral cooperation but revolves around the school teachers. ${ }^{1,2}$ The school age group might form as much as a quarter of the whole population, so this underscores how important a health service is for them. ${ }^{3}$ Although the detailed organization of school health programme varies from one place to the other, in Nigeria, it focuses on integrated activities with five main components including healthful school environment, school health education, school health services, school nutrition program, and school, home and community relationship. ${ }^{4}$ Children at any stage of education need good health and freedom from disease, handicap or disability in order to benefit maximally from their education. For some of the children, especially those from less privileged homes, the school may offer them the only opportunity of benefiting from health care services and acquiring knowledge through health education on how to improve on personal or environmental hygiene. In an ideal situation, every child should undergo a clinical examination before he/she is registered in school, and this should start from the period of preschool education (nursery), and should then be repeated at the beginning of the primary and secondary school. This is particularly relevant in a developing country like Nigeria where many children of school age are survivors in an environment of very high perinatal, neonatal, infant and under-five mortality rates. 5

School-age children account for about 23 percent of the population in the average community in Nigeria, ${ }^{6}$ and their health status and indices are useful in determining a nation's state of development. ${ }^{6}$ Over the last decade, Nigeria's exponential growth in population has put immense pressure on the country's resources and on the already overstretched public services and infrastructure. With children under 15 years of age accounting for about 45 per cent of the country's population, the burden on education and other sectors has become overwhelming. ${ }^{7}$

In Nigeria, implementation of the SHP is generally poor, 8 with very few schools engaging in pre-entry and periodic medical examinations, most schools with inadequate content of first aid box and without school clinic or sick bay even though the Implementation Guidelines on National School Health Programme have been in existence since 2006.9 The National School Health Policy recognizes that the various services provided in SHP are highly technical and require the acquisition of appropriate knowledge and continuous skills development for teachers. ${ }^{10}$ Lack of basic knowledge of the programme among teachers will hinder its effective implementation. ${ }^{11}$ Studies that assess teachers' knowledge of SHP are needed to improve the current suboptimal level of implementation in Nigeria, ${ }^{11}$ as they are the resource persons responsible for the promotion and successful implementation of the school health programme. ${ }^{6}$ Adebayo and Onadeko in 2015 reported that, only $1.7 \%$ of primary school teachers in Oyo State, south western Nigeria could correctly state that the purpose of SHP is to promote 
and maintain the wellbeing of both pupils and staff. A vast majority (96.2\%) of primary school teachers did not know any of the components of SHP while $3.8 \%$ knew at least one component. ${ }^{6}$ Amoran et al., in 2016 reported that most $(92.2 \%)$ of public primary school teachers in Ogun state had poor knowledge of SHP. 12 Ofovwe and Ofili in 2007 reported that knowledge of SHP was adequate in only $6.9 \%$ of public primary school teachers in Egor Local Government Area of Edo State. ${ }^{2}$ A similar study conducted among teachers in Osun State, Nigeria, reported that overall knowledge of SHP was good in only about half $(50.7 \%)$ of respondents. ${ }^{13}$

The role of teachers in the school health programme is very crucial, because of their opportunity to influence large numbers of children and their parents and enable schools integrate health initiatives in such a way as to address many of the children and societal health issues. ${ }^{6,14}$ Teachers are well respected and are viewed as role models by their students and they have an important impact on their learning and action. ${ }^{15}, 16$ Therefore, the success of school-based health programme relies on their knowledge, attitude and perspective on the health needs of students. ${ }^{6}$ This study is very important in the sense that apart from establishing the current status of knowledge of SHP among primary school teachers in our locality, it would provide a basis for conducting health education intervention in improving knowledge of SHP as earlier documented in previous studies. ${ }^{17-19}$ Therefore, this study was conducted to assess the knowledge of school health programme among primary school teachers in Sokoto metropolis, northwestern, Nigeria.

\section{METHODOLOGY}

\section{Study Area}

This study was carried out in Sokoto metropolis the capital of Sokoto State in north-western Nigeria. The metropolis comprises of Dange-Shuni, Sokoto North, Sokoto South and Wamakko Local Government Areas (LGAs) with an estimated population of 937,471 using a population growth of 3.01 in 2018. ${ }^{20}$ Sokoto State has 1,963 public primary schools, an enrolment of 610,886 (400,381 male; 210,505 female) pupils, and this gives a Net Enrolment Rate (NER) of 55.5\% and Gross Enrolment Rate (GER) of $71 \% .{ }^{21}$ There are 12,737 teachers (9,091 males and 3,646 female) among which only 4,247 males and 1,246 females are qualified teachers which gives a teacherpupil ratio of $1: 47$ and $1: 14$ respectively. ${ }^{21}$ The metropolitan LGAs has 3017 teachers working in 209 government primary schools in the state. Two hundred and six schools are co-educational and day schools while three are boarding schools. Majority of the schools operate during the morning hours (7:30am- $12: 30 \mathrm{pm})$ while a few (mostly Arabic primary schools) operate during the evening hours. The coordination of the entire school's system rests on the State Ministry of Education and the State Universal Primary Education Board.

\section{Study Design and Population}

A cross-sectional study was conducted among primary school teachers from 
January to March 2018. Only teachers in public primary schools registered by the government and who have worked for at least one year were considered eligible. We excluded teachers in training (teaching practice) and temporary or substitute teachers.

\section{Sample Size Estimation and Sampling Technique}

The sample size was estimated at 382 using the statistical formula for calculating the sample size for descriptive studies $n=$ $Z a^{2} p q / d^{2}, 22$ with a $62.0 \%$ proportion of teachers with good knowledge of SHP from a previous study, ${ }^{23}$ and a precision level (d) of 5\%. However, adjustment for a finite population of 3017 primary school teachers in Sokoto metropolis was done, ${ }^{24}$ and an anticipated $95 \%$ response rate. The eligible participants were selected using a multistage sampling technique. In the first stage, two of four metropolitan LGAs Dange-Shuni and Wamakko - were selected by balloting. In the second stage, a list of all the schools within the two selected metropolitan LGAs was obtained from the Ministry of Education Sokoto State, Nigeria. Twenty-one out of 82 schools and 19 out of 74 schools were selected by simple random sampling in Dange-Shuni and Wamakko LGAs, respectively; and proportionate allocation was done in the selection of schools from the two LGAs. In the third stage, systematic sampling technique was used to recruit the study participants using a sampling frame of 1865 teachers obtained from the respective schools in the two selected LGAs. In order to achieve this, a sampling interval of 5 was generated and the first teacher was determined by selecting a number between 1 and 5 using simple random sampling method by balloting. Subsequently, every $5^{\text {th }}$ teacher on the staff list in the respective schools was selected until the required sample size of 382 was obtained.

\section{Data Collection and Analysis}

A pretested structured self-administered questionnaire was used to collect data on the respondents' socio-demographic characteristics and knowledge of SHP. The questions were adapted from questionnaires from previous studies, $6,13,23$ the face and content validity were reviewed and approved by senior researchers in the area of school health, whereas the test-retest reliability was conducted to establish the reliability of the instrument. The questionnaire was pretested on 38 primary school teachers in Kware LGA, Sokoto State, Nigeria, which is about $35 \mathrm{~km}$ away from the study area. Appropriate corrections were made based on the deficiencies detected in the instrument during the pretesting. Four graduates and two undergraduates of tertiary institutions in Sokoto State were recruited, trained and deployed for data collection which lasted for 3 weeks. The training focused on the conduct of research, including research ethics, objectives of the study and use of the survey instrument.

The knowledge section consists of 122 questions addressing the subthemes: knowledge of objectives of SHP; knowledge of components of SHP; knowledge of 
activities carried out in school health services; knowledge of services providers in SHP; knowledge of conducting pre-entry screening and periodic inspection of pupils; knowledge of contents of first aid box; knowledge of first aid services that can be carried out by teachers in schools; knowledge of diagnostic materials that should be available in schools; knowledge of school nutritional program; and knowledge regarding school, home and community relationship. Some dud (negative) questions were included (i.e. reversely phrased) in all the subthemes in order to confirm if the respondents actually knew the answers or not. Correct responses to knowledge of school health programme were scored one mark, while incorrect and no response were scored zero, and the aggregate scores for each subthemes were reported in proportions. Knowledge scores $\geq 50 \%$ and $<50 \%$ were graded as good and poor knowledge, respectively. ${ }^{11}$

Descriptive statistical analysis such as mean and standard deviation were done for continuous variables, while categorical data were presented in frequencies and proportions. Chi-square and Fisher's exact test were performed to determine the association between socio-demographic variables and knowledge of SHP, while binary logistic regression model was used to identify the predictors of good knowledge of SHP. The IBM SPSS ${ }^{\circledR}$ version 23.0 software was used for the analysis. All levels of significance were set at $\mathrm{p}<0.05$.

\section{Ethical Consideration}

Ethical clearance was obtained from the Research Ethics Committee of Sokoto State Ministry of Health, Sokoto, Nigeria with reference number SMH/1580/2016/V. IV. Permission to conduct the study was obtained from the Honourable Commissioner, Ministry of Education, Sokoto State, Nigeria. Respondents were assured of strict confidentiality of their responses and were also informed that their participation was voluntary and would incur no penalty if they refuse to participate in the study.

\section{RESULTS}

All the 382 questionnaires administered were adequately completed and used for analyses giving a response rate of $100 \%$. One hundred and forty-three (37.4\%) respondents were aged $30-39$ years (mean age $=34.8 \pm 8.6$ years). Majority $218(57.1 \%)$ of the respondents were males, married 241 (63.1\%), belong to Hausa ethnic group 282 (73.8\%), had NCE certificate 245 (64.1\%) and have served for less than 10 years 215 (56.3\%) as shown in Table 1. One hundred and ninety-eight $(51.8 \%)$ respondents had good knowledge of school health programme. The area of SHP most commonly known to the respondents was the reasons for skilled-based health education and physical education in schools $308(80.6 \%)$. While the area on the reasons for carrying out pre-entry screening and periodic inspection of pupils in school was the least commonly known to the respondents 163 (42.7\%) (Table 2). 
The proportion of respondents with good knowledge of SHP, 67 (61.5\%) was higher among the primary school teachers that were aged $\geq 40$ years as compared to those that were aged $<40$ years $131(48.0 \%)$ and the difference observed was statistically significant $\left(\chi^{2}=5.672, p=0.017\right)$. Similarly, the proportion of respondents with good knowledge of SHP was higher among primary school teachers who had degree or postgraduate qualification in education 78 $(78.8 \%)$ as compared to those who had secondary certificate, grade II or National Certificate on Education (NCE), 120 (42.4\%) and the difference observed was statistically significant $\quad\left(\chi^{2}=38.891\right.$, $\mathrm{p}<0.001)$. In addition, the proportion of respondents with good knowledge of SHP was higher among primary school teachers who had served for $\geq 2$ decades 26 (83.9\%) as compared to those who had served for less than two decades 172 (49.0\%) $\left(\chi^{2}=13.871, \mathrm{p}<0.001\right)$ as shown in Table 3.

Primary school teachers who had degree or postgraduate certificate in education were 5 times more likely to have good knowledge as compared to those who had secondary school certificate, Grade II or Nigerian Certificate in Education (NCE) (aOR: 4.55; 95\% CI=2.63-7.69, $\mathrm{p}<0.001)$. Also, those who have served two or more decades were 4 times more likely to have good knowledge as compared to those who have served for less than two decades (aOR: 4.15; 95\% $\mathrm{CI}=1.34-12.78, \mathrm{p}=0.011$ ) (Table 4).

\section{DISCUSSION}

This study assessed the knowledge of school health programme among primary school teachers in Sokoto metropolis. Majority of respondents were in the second and third decades of life. The age distribution in this study is in discordance with what was reported in studies in South-western Nigeria, ${ }^{11,25}$ where majority of respondents were in their fourth decade of life. This variation could be as a result of the recent employment of teachers by the Sokoto state government in which most of them were fresh graduates. Men formed more than half of the respondents and the predominance of male in this study is not surprising especially in the Northern part of Nigeria due to the disparity in educational attainment between males and females, and with higher proportions of males being enrolled into schools as compared to females, ${ }^{21}$ so they end up having the requirements for employment as teachers in contrast to their female counterparts. In addition, many of the females after graduation are not permitted by their spouses to work because of the puddah system. This was not the case in studies conducted in Ogun and Oyo States of Nigeria and in Danuphyu Township, Ayeyarwaddy Region, Myanmar where majority of teachers were females, $6,11,23$ and it indicates higher female education rates in the southern part of Nigeria and other countries as compared to the Northern Nigerian region. Majority of the respondents were married, this finding is in consonance 
Table I: Socio-demographic characteristics of the respondents

\begin{tabular}{|c|c|c|}
\hline Variables & $\begin{array}{c}\text { Frequency } \\
(n=382)\end{array}$ & Percent \\
\hline \multicolumn{3}{|l|}{ Age group (years) } \\
\hline $20-29$ & 130 & 34.0 \\
\hline $30-39$ & 143 & 37.4 \\
\hline $40-49$ & 82 & 21.5 \\
\hline $50-59$ & 21 & 5.5 \\
\hline$\geq 60$ & 6 & 1.6 \\
\hline \multicolumn{3}{|l|}{ Sex } \\
\hline Male & 218 & 57.1 \\
\hline Female & 164 & 42.9 \\
\hline \multicolumn{3}{|l|}{ Marital status } \\
\hline Single & 126 & 33.0 \\
\hline Married & 241 & 63.1 \\
\hline Divorced & 5 & 1.3 \\
\hline Widowed & 10 & 2.6 \\
\hline \multicolumn{3}{|l|}{ Religion } \\
\hline Islam & 348 & 91.1 \\
\hline Christianity & 34 & 8.9 \\
\hline \multicolumn{3}{|l|}{ Ethnicity } \\
\hline Hausa & 282 & 73.8 \\
\hline Fulani & 48 & 12.6 \\
\hline Yoruba & 22 & 5.8 \\
\hline Igbo & 7 & 1.8 \\
\hline Others & 23 & 6.0 \\
\hline \multicolumn{3}{|l|}{ Educational Qualification } \\
\hline Secondary & 27 & 7.1 \\
\hline Grade II & 11 & 2.9 \\
\hline $\mathrm{NCE}$ & 245 & 64.0 \\
\hline Degree & 90 & 23.6 \\
\hline Postgraduate & 9 & 2.4 \\
\hline \multicolumn{3}{|c|}{ Type of School by Accommodation } \\
\hline Day & 348 & 91.1 \\
\hline Both Day and Boarding & 34 & 8.9 \\
\hline \multicolumn{3}{|l|}{ Years of Service (years) } \\
\hline$<10$ & 215 & 56.3 \\
\hline $10-19$ & 136 & 35.6 \\
\hline $20-29$ & 23 & 6.0 \\
\hline$\geq 30$ & 8 & 2.1 \\
\hline
\end{tabular}

Others = Zabarmawa, Nufawa, Dakkarawa, NCE=Nigerian Certificate in Education

with what was reported by Adebayo in Oyo State South-western Nigeria. ${ }^{11}$ These findings could be supported by the fact that teaching profession is one of the culturally acceptable profession in the north that allows married women to engage in freely. In addition, it could also be that they would have reached the age for marriage by the time they obtain the basic requirement for employment as teachers. Majority of the respondents were holders of Nigerian Certificate in Education (NCE) from Colleges of Education. This finding is in concordance with what was reported in Ogun South-west and Edo South-south Nigeria, where most of the respondents graduated from the Colleges of education. ${ }^{2}, 12$ However, this finding is in discordance with the reports from studies that were conducted in Sagamu and Ibadan South-western Nigeria where most of the teachers were at least first degree holders. ${ }^{11,25,26}$ A plausible explanation for this variation could be due to the fact that this study was among primary school teachers only as opposed to the studies conducted in Sagamu and Ibadan 


\begin{tabular}{lll}
\hline Knowledge domains & $\begin{array}{l}\text { Correct } \\
\text { Frequency } \\
\text { (n=382) }\end{array}$ & $\begin{array}{l}\text { Responses } \\
\text { Percent }\end{array}$ \\
\hline Objectives of SHP & 261 & 68.3 \\
Components of SHP & 215 & 56.3 \\
SHP improves academic performance of school children & 178 & 46.6 \\
Healthful school environment in SHP & 264 & 69.1 \\
Environmental safety in schools & 276 & 72.3 \\
Activities carried out in school health services & 256 & 67.0 \\
Health service provision in SHP & 208 & 54.5 \\
Service providers in SHP & 204 & 53.4 \\
Pre-entry medical screening or examination is compulsory based on & 163 & 42.7 \\
the national guideline & & 76.2 \\
Reasons for carrying out pre-entry screening and periodic inspection & 291 & 72.5 \\
of pupils in schools & & 50.5 \\
Content of first aid box & 277 & 57.3 \\
First aid services that can be carried out by teachers in schools & 193 & 80.6 \\
Diagnostic materials that should be available in schools & 219 & 62.8 \\
Reasons for skilled-based health education and physical education in & 308 & 77.0 \\
schools & & 240 \\
Reasons for school nutritional program & 294 & 48.2 \\
Reasons for school, home and community relationship & & 51.8 \\
Knowledge grading & 184 & 198 \\
Poor knowledge & & \\
Good knowledge & & \\
\hline SHP & & \\
\hline
\end{tabular}

SHP - School Health Programme

where they interviewed both the primary and secondary school teachers. Most of the respondents have been in service for less than 10 years. The finding in this study is similar to what was reported in Osun where majority of the respondents had been in service for 5 years or more. ${ }^{13}$ However, the finding is in discordance with what was reported by Adebayo in Oyo and Htun et al in Myanmar. ${ }^{11,23}$

The overall knowledge of school health program was good in about half of the respondents. The deficient concept of school health program which appears to prevail in
Nigeria may play a vital role in the relatively poor knowledge of SHP among primary school teachers in this study. The findings in this study agree with the findings in a number of similar studies in Nigeria and abroad. A study in Osun South-western Nigeria reported good knowledge of SHP in about half $(49.8 \%)$ of respondents in the public primary schools in the state. 13 Similarly in a study carried out in Myanmar south East Asia, $62.0 \%$ of the teachers demonstrated high level of knowledge with regards to specified school health activities. ${ }^{23}$ In contrast to the findings in this study, a study carried out in Edo, 
Table 3: Relationship between sociodemographic variables and knowledge of school health program

\begin{tabular}{|c|c|c|c|}
\hline \multirow[t]{3}{*}{ Variables } & \multicolumn{2}{|c|}{ Knowledge Grading } & \multirow{3}{*}{$\begin{array}{l}\text { Test Statistics } \\
\text { p-value }\end{array}$} \\
\hline & Poor $(n=184)$ & $\begin{array}{c}\text { Good } \\
(n=198)\end{array}$ & \\
\hline & n (\%) & n (\%) & \\
\hline \multicolumn{4}{|l|}{ Age group } \\
\hline$<40$ years & $142(52.0)$ & $131(48.0)$ & \multirow{2}{*}{$\begin{array}{l}\chi^{2}=5.674 \\
\mathbf{p}=\mathbf{0 . 0 1 7}\end{array}$} \\
\hline$\geq 40$ years & $42(38.5)$ & $67(61.5)$ & \\
\hline \multicolumn{4}{|l|}{ Sex } \\
\hline Male & 101 (46.3) & $117(53.7)$ & \multirow{2}{*}{$\begin{array}{l}\chi^{2}=0.687 \\
p=0.407\end{array}$} \\
\hline Female & $83(50.6)$ & $81(49.4)$ & \\
\hline \multicolumn{4}{|l|}{ Marital status } \\
\hline Never married & $60(47.6)$ & $66(52.4)$ & \multirow{2}{*}{$\begin{array}{l}\chi^{2}=0.023 \\
p=0.880\end{array}$} \\
\hline Ever married & $124(48.4)$ & $132(51.6)$ & \\
\hline \multicolumn{4}{|l|}{ Religion } \\
\hline Islam & 177 (50.9) & $171(49.1)$ & \multirow{2}{*}{$\begin{array}{l}\chi^{2}=11.370 \\
\mathbf{p}<\mathbf{0 . 0 0 1}\end{array}$} \\
\hline Christianity & 7 (20.6) & 27 (79.4) & \\
\hline \multicolumn{4}{|l|}{ Ethnicity } \\
\hline Hausa/ Fulani & $174(52.7)$ & $156(47.3)$ & \multirow{2}{*}{$\begin{array}{l}\chi^{2}=20.188 \\
\mathbf{p}<\mathbf{0 . 0 0 1}\end{array}$} \\
\hline Others & $10(19.2)$ & $42(80.8)$ & \\
\hline \multicolumn{4}{|l|}{ Qualification } \\
\hline Secondary/Grade II/NCE & $163(57.6)$ & $120(42.4)$ & \multirow{2}{*}{$\begin{array}{l}\chi^{2}=38.891 \\
\mathbf{p}<\mathbf{0 . 0 0 1}\end{array}$} \\
\hline Degree/Post graduate & $21(21.2)$ & $78(78.8)$ & \\
\hline \multicolumn{4}{|c|}{ Type of School by accommodation } \\
\hline Day & $173(49.7)$ & $175(50.3)$ & \multirow{2}{*}{$\begin{array}{l}\chi^{2}=3.739 \\
p=0.053\end{array}$} \\
\hline Both day and boarding & $11(32.4)$ & $23(67.6)$ & \\
\hline \multicolumn{4}{|l|}{ Years of Service } \\
\hline$<2$ decades & $179(51.0)$ & $172(49.0)$ & \multirow{2}{*}{$\begin{array}{l}\chi^{2}=13.871 \\
\mathbf{p}<\mathbf{0 . 0 0 1}\end{array}$} \\
\hline$\geq 2$ decades & $5(16.1)$ & $26(83.9)$ & \\
\hline
\end{tabular}

NCE = Nigerian Certificate in Education, Others = Yoruba, Igbo, Zabarmawa, Nufawa, Dakkarawa

Nigeria reported that overall knowledge of SHP was good in only $6.9 \%$ of respondents from the public primary schools in the state. ${ }^{2}$ Similarly in a study carried out in Ogun, Nigeria only about $18.4 \%$ of primary school teachers in Efo and 14.3\% in Ekenne demonstrated good knowledge of school health program. ${ }^{6}$ The proportion of respondents with overall good knowledge of SHP could be explained by the knowledge of the respondents in various sub-themes of questions that assessed the knowledge of school health program. For example, relatively high proportion of respondents knew the objectives of SHP as compared to the finding in a study conducted in Oyo in which only a few $(1.7 \%)$ could correctly state that the purpose or objectives of SHP is to promote and maintain the wellbeing of both pupils and staff. 11 This variation could be due to the fact that the study in Oyo used an open ended question approach compared to the closed ended questions used for this study, hence, this may affect the overall finding. The factors that were found to be significantly associated with good 


\begin{tabular}{|c|c|c|c|c|}
\hline \multirow[t]{2}{*}{ Variables } & \multirow[t]{2}{*}{ aOR } & \multicolumn{2}{|c|}{ 95\% CI } & \multirow[t]{2}{*}{ p-value } \\
\hline & & lower & Upper & \\
\hline $\begin{array}{l}\text { Age (years) } \\
\left(<40 \text { vs } \geq 40^{*}\right)\end{array}$ & 0.67 & 0.39 & 1.16 & 0.152 \\
\hline $\begin{array}{l}\text { Sex } \\
(\text { Male vs Female*) }\end{array}$ & 1.09 & 0.68 & 1.73 & 0.696 \\
\hline $\begin{array}{l}\text { Marital status } \\
\text { (Never married vs Ever married*) }\end{array}$ & 1.47 & 0.87 & 2.49 & 0.170 \\
\hline $\begin{array}{l}\text { Religion } \\
\text { (Islam vs Christianity*) } \\
\text { Ethnicity }\end{array}$ & 1.06 & 0.27 & 4.18 & 0.954 \\
\hline $\begin{array}{l}\text { (Others vs Hausa/Fulani*) } \\
\text { Educational qualification }\end{array}$ & 3.70 & 1.11 & 12.50 & 0.034 \\
\hline (Degree/Post graduate vs Secondary/Grade II/ $\mathrm{NCE}^{*}$ ) & 4.55 & 2.63 & 7.69 & $<0.001$ \\
\hline $\begin{array}{l}\text { Type of School by Accommodation } \\
\text { (Day school vs Both day and boarding*) }\end{array}$ & 1.22 & 0.80 & 1.86 & 0.339 \\
\hline $\begin{array}{l}\text { Year of service } \\
(\geq 2 \text { decades vs }<2 \text { decades } *)\end{array}$ & 4.15 & 1.34 & 12.78 & 0.011 \\
\hline
\end{tabular}

knowledge of SHP in this study were age, religion, ethnicity, educational qualification and year of service. Similar findings were reported in other studies conducted in Oyo state South-western Nigeria and in Myanmar South-eastern Asia. ${ }^{11,23}$ When these factors were inserted into a regression model, ethnicity, educational qualification and year of service were found to be significant predictors of good knowledge of school health programme. This finding is similar to what was reported in Oyo Southwestern, Nigeria. ${ }^{11}$ Hence, the findings in this study are not surprising for the fact that teachers that have higher educational qualifications tend to be more knowledgeable as against those with lower educational qualifications as a result of greater access to information, learning materials and exposure. In addition, the reason for ethnicity being the predictor could be due to relatively smaller proportion of respondents from other ethnicity as compared to Hausa/Fulani which may influence the knowledge of SHP. It could also be possible that the respondents from other ethnicity are among those that have higher educational qualification or the highly experienced.

It is worthy to note that the study enables us to know that knowledge of SHP was barely average among the respondents and identified factors that predict knowledge of SHP that could be used as evidence-based information in recommending to the Sokoto State Ministry of Education (MoE) and Sokoto State Teachers Service Board (TSB) to address the knowledge gaps identified. However, major weakness identified in this study was that information on the availability of the National Guidelines on SHP and also whether teachers had received training on SHP either during pre-service or service were not obtained. This would have enabled us to ascertain the level of implementation of the programme in addition to providing additional evidence for 
the cause of the deficiencies identified in their knowledge. This is suggested for further research. Deliberate misinformation by the respondents was anticipated. This limitation was minimized by educating the study subjects on the importance of the study and also by informing them that the information given cannot be traced back to them. Guessing is a possibility when answering the questions. This may distort the true measure of knowledge of SHP. To minimize guessing, a "don't know" option was included in the list of responses and "dud (negative) questions" were included in the list of variables in order to check that respondents actually know the answers that assessed knowledge.

Conclusion: Knowledge of school health programme was good in about half of public primary school teachers in Sokoto State with ethnicity, educational qualification and years of service being the predictors of good knowledge of SHP. Sokoto State Ministry of Education through the UBE should provide periodic training for primary school teachers on SHP to ensure that school age children remain healthy and derive maximum benefit from their education.

Acknowledgements: The authors appreciate the Honorable Commissioner, Ministry of Basic and Secondary Education, Sokoto State, Nigeria; the Honorable Commissioner, Ministry of Health, Sokoto State, Nigeria; Sokoto State Universal Basic Education Board (SUBEB); the head teachers of the respective schools and primary school teachers that participated in the study for their cooperation.
Competing interests: The authors declare that there were no conflicts of interest.

Authors' contributions: The authors listed in this manuscript contributed significantly and their contributions were as follows; AUA created the concept, did literature search, data review, analysis and drafting of the manuscript. OMO and KJA critically reviewed the concept and drafting of the manuscript. IAR, AMA and AUK all critically reviewed and edited the manuscript. All the authors read and agreed to the final manuscript.

\section{REFERENCES}

1. Akani NA, Nkanginieme KE. The School Health Program. 2nd ed. Owerri Nigeria: AES; 2007.

2. Ofovwe G, Ofili AN. Knowledge, attitude and practice of school health programme among head teachers of primary schools in Egor Local Government Area of Edo State, Nigeria. Ann Afr Med Soc. 2007; 6(3): 99103. DOI: $10.4103 / 1596-3519.55726$

3. Jellife D. Child health in the tropics. 5th ed. Ibadan, Nigeria: Bounty press Ltd; 2006.

4. Federal Ministry of Education. Implementation Guidelines on National school health programme. In: Education FMo, editor. Abuja, Nigeria 2006.

5. Obionu C. Primary Health Care for developing countries. 2nd ed. Enugu, Nigeria: Delta publications Nigeria Ltd; 2007.

6. Odeyemi K, Chukwu E. Knowledge, attitude and practice of school health among primary school teachers in Ogun State, Nigeria. Nig J Paediatr. 2015; 42(4): 340345. doi.org/10.4314/njp.v42i4.11

7. UNICEF. Koranic schools in Nigeria join the drive for universal education. United Nations Children's Fund; 2005.

8. Akani N, Nkanginieme K, Oruamabo R. The school health programme: A situation revisit. Nig J Paediatr. 2001; 28(1): 1-6. DOI: $10.4314 /$ njp.v28i1.12046

9. Oluyinka D, Ayodeji MA. School Health Program in Nigeria: A Review of its 
Implementation for Policy Improvement. Am J Edu Res. 2019; 7(7): 499-508. DOI:10.12691/education-7-7-10

10. Federal Ministry of Education. National School Health Policy (NSHP). In: Education FMo, editor. Abuja 2006.

11. Adebayo AM, Onadeko MO. Knowledge of school health programme among public primary school teachers in Oyo State, south-west Nigeria: A rural-urban comparative study. Afr J Reprod Health. 2015; 19(3): 55-60

12. Amoran O, Kuponiyi O, Opeyemi K. Head teachers' perception and practice about school feeding services in public and private primary schools in Ogun State, Nigeria. $\mathrm{Br}$ J Edu Soc Behav Sci. 2016; 13(1): 1-11. DOI: 10.9734/BJESBS/2016/22072.

13. Abodunrin OL, Adeoye DA, Adeomi A, Osundina F, Ilori D. Practice scope and determinant of school health services in Osun State, Nigeria. Br J Med Med Res 2014; 4(35): $5548 \quad-5557$. doi.org/10.9734/BJMMR/2014/11931

14. Sukhabogi J, Shekar B, Hameed I. Knowledge, attitude and practices related to oral health among English and Telugu medium school teachers in two districts of Andhra Pradesh, India: A comparative study. J Indian Assoc Public Health Dent. 2014; 12(4): 306-311. DOI: 10.4103/2319$\underline{5932.147675}$

15. Eric A, Hanushell, FW. School teachers, educational outcomes in developing countries: In Handbook of the Economics of Education. Amsterdam: IOS press; 2006.

16. Ibeziako P, Bella T, Omigbodun, Belfer M. Teacher's perceptive of mental health needs in Nigerian schools. J Child Adolesc Mental Health. 2009; 21(2): 147-156. DOI: 10.2989/JCAMH.2009.21.2.6.1014

17. Abdella NH, Abu-Elina NR, Elkazaz RH, Moussa $M$. Intervention program for the kindergarten teachers about pediatrics first aids. Am J Res Commun. 2015; 3(5): 179194

18. Barrett J. Teaching teachers about school health emergencies. The J Sch Nurs. 2001; 17(6): 316-322. DOI: $\underline{10.1177 / 10598405010170060601}$

19. Jha N, Bajracharya O, Shankar P. Knowledge, attitude and practice towards medicines among school teachers in
Lalitpur district, Nepal before and after an educational intervention. BMC Public Health 2013; 13: 652. DOI: 10.1186/14712458-13-652

20. National Population Commision (NPC) [Nigeria]. Population Disribution by Sex, State, LGA and Senatorial District. Abuja, Nigeria: The Federal Government Printer; 2010. Available from: https://www.google.com/url?sa=t\&source =web\&rct=j\&url=http:/ / catalog.ihsn.org/i ndex.php/catalog/3340/download/48521 \&ved=2ahUKEwjMp7qY3uvsAhXXQEEAHT oCjsQFjAAegQIARAB\&usg=AOvVaw1TeZvj 2pfYWGSfvo6_zMS2\&cshid=16045907820 86.

21. Ministry of Education Sokoto. State Strategic Education Sector Plan (Sesp) 2011 - 2020. 2010 Available from:. https: / / www.google.com/url?sa $=t \& r c t=j \& q$ $=\&$ esrc $=$ s\&source $=$ web\&cd $=1 \&$ ved $=2$ ahUK EwjbnYGaqrPdAhUNVsAKHW1GDKMQFjA AegQIABAC\&url=https\%3A\%2F\%2Fwww.gl obalpartnership.org $\% 2$ Fdownload $\% 2$ Ffile $\%$ 2Ffid\%2F46613\&usg=AOvVaw0XjHQK870 gnswE8M1-1EPN

22. Ibrahim T. Research Methodology and Dissertation writing for Health \& Allied Health Professionals. 1st ed: Cress Global Link Abuja; 2009.

23. Htun Y, Lwin K, Nwe O, Soe K, Sein T. Knowledge, attitude and reported practice of primary school teachers on specified school health activities in Danuphyu Township, Ayeyarwaddy Region, Myanmar. South East Asia J pub hlth. 2013; 3(1): 2429. DOI: $10.3329 /$ seajph.v3i1.17707

24. Kirkwood B, Sterne J. Essential Medical statistics. $2^{\text {nd }}$ ed: Oxford Medical publications; 8 May 2003.

25. Obembe TA, Osungbade KO, Ademokun OM. Awareness and knowledge of National School Health Policy and School Health Programme among public secondary school teachers in Ibadan metropolis. Nig Med J. 2016; 57(4): 217-225. DOI: $10.4103 / 0300-1652.188341$

26. Oyinlade A, Ogunkunle O, Olarenwaju D. An evaluation of school health services in Sagmu, Nigeria. Nig J Clin Pract. 2014; 17(3): 336-432. DOI: $10.4103 / 1119-3077.130236$ 